and development projects which are quite new, at least in British universities. It has in mind, for example, the way in which a number of universities in the United States have been able to surround themselves with research institutes with specialized interests in various kinds of industries. Among the kinds of projects it would like to encourage in Britain are, for example, schemes which might yield industrial and economic benefits by making it possible to manufacture electronic components more reliably and therefore more cheaply. No doubt it would look favourably on projects whose results might be a shortening of the time spent on developments of all kinds. But it seems also aware of the way in which the effectiveness of British industry could be enhanced by the development and introduction of schemes for training specialists of various kinds with great despatch.

\section{More Facts about Schools}

THE latest Statistics of Education (HMSO, £1 $7 s .6 d$.) are a rich lode for sociologists. As well as providing further evidence of the distaste for science in the schools, the tables provide fascinating information on the sociology of immigration. In the country as a whole, immigrant children (defined as those who were born outside the UK, or whose parents came to the UK after January 1,1956 ) make up only 1.8 per cent of the school population. But there are wide variations -in the Inner London Education Authority $12 \cdot 1$ per cent of the pupils are immigrants, while the Welsh authorities have only $0 \cdot 1$ per cent, despite Tiger Bay. In the northern region, children from India and Pakistan make up the vast majority of immigrant children, 87.8 per cent between them, but in London they make up only $15 \cdot 1$ per cent, and West Indian children take the largest share, $46 \cdot 6$ per cent.

Perhaps these differences go some way towards explaining the differences in the knowledge of English among immigrant children. In London 55 per cent of the children have no problem with their English, while only 3.5 per cent have no English at all; in the north $7 \cdot 1$ per cent have no English, and only $44 \cdot 7$ per cent can claim that their English is entirely adequate.

The figures disclose a further decline in the numbers of children studying the mathematics/science subjects in the sixth form. This group accounted for 53 per cent of the maintained school sixth forms in 1963, but it was down to 47.8 per cent in 1966 . The actual numbers in this option had declined from 47,140 in 1965 to 46,599 in 1966 . Some educationists may see it as a comfort that the number of children in the sixth form who mix science subjects with the humanities continues to increase. This group now accounts for 12.9 per cent of the sixth form population, against 8.7 per cent four years ago; the actual numbers in this option have almost doubled since 1963 .

\section{Galapagos Preserved}

WhILE the Ministry of Defence contemplates the destruction of Aldabra by an air staging post, the Galapagos Islands at least are in good hands. The Charles Darwin Foundation for the Galapagos Islands, founded in 1959 , has had a research station on Santa
Cruz Island since 1961. Scientists have been carrying out ecological survey work with a view to deciding how best to preserve these islands, whose animals (most notably the finches) resembling but differing slightly from those of mainland South America made Darwin realize the full importance of geographical isolation in evolution. Many of the animals belong to a subspecies peculiar to these islands, and the marine iguana, unique in the world, is also the only sea-going lizard. The scientists are producing a plan for the conservation of this wildlife. The government of the Republic of Ecuador, which owns the islands, already gives financial support to the research station, and will shortly pass a law declaring parts of the archipelago a national park. Within these areas the wildlife will be completely preserved. There may be some careful direction of the forces of selection to protect any animals in danger from others. The seals may be culled to prevent them from harming the fish population. The flamingo, which was thought to be in danger of extinction, has been found an area where it can live, and it is now out of danger.

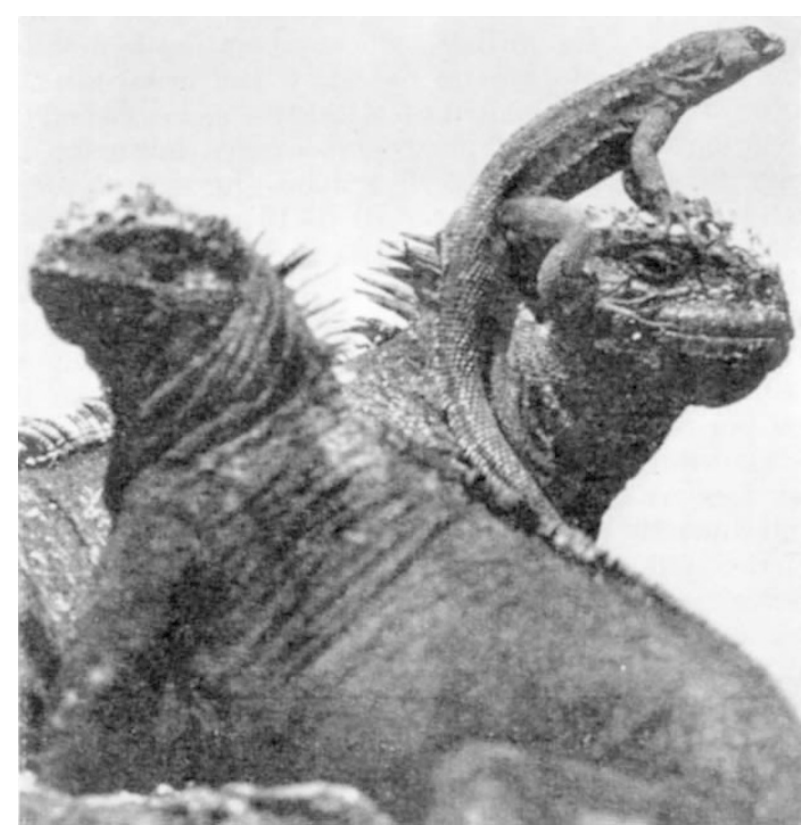

Marine iguanas in the Galapagos.

The national park of the Galapagos Islands could become an attraction for luxury tourism. Visitors will come on cruising ships and by air, to tour the islands by boat, under strict supervision. They will be expected to pay heavily, and help to subsidize the conservation work. Private enterprise, which is involved in the air traffic to the islands-there is already an air stripcontributes to the research station. But the Darwin Foundation is still forced to appeal for money to replace the forty-year-old ex-Cornish fishing vessel, Beagle II, which has been essential to the research staff in their work on the islands. Anglia TV has made a colour film, "The Enchanted Isles", which is to have a special royal showing at the National Film Theatre on November 27, when the foundation hopes to raise $£ 20,000$ to build a ship that will stand up to the rough South American seas. 